\title{
PATH ANALYSIS ON THE FACTORS ASSOCIATED WITH MIDWIFE PERFORMANCE AT HEALTH CENTER IN EAST KALIMANTAN, INDONESIA
}

\author{
Latifah Nur Rahmadani'), Uki Retno Budihastuti'), \\ Eti Poncorini Pamungkasari2) \\ ${ }^{1)}$ Masters Program in Public Health, Universitas Sebelas Maret \\ 2)Department of Obstetrics and Gynecology, Dr. Moewardi Hospital, Surakarta \\ 3)Faculty of Medicine, Universitas Sebelas Maret
}

\begin{abstract}
Background: Ensuring a good performance of midwives is one of the key components for provision of quality maternal health service. Skilled midwifery is widely recognized as a critical factor in reducing maternal and infant mortality. This study aimed to examine factors associated with midwives performance at health center in East Kalimantan, Indonesia.

Subjects and Method: This was a cross-sectional study conducted at 25 community health centers (puskesmas) in Samarinda, East Kalimantan, Indonesia, from April to May 2019. A sample of 180 midwives was selected by total sampling. The dependent variable was work performance. The independent variables were knowledge, tenure, training, work burden, incentive, supervision, and motivation.

Results: Work performance of midwives was directly and positively affected by good knowledge $(b=1.42 ; 95 \% \mathrm{CI}=0.54$ to $2.31 ; \mathrm{p}=0.001)$, tenure $\geq 13$ years $(b=2.06 ; 95 \%$ $\mathrm{CI}=1.01$ to $3.11 ; \mathrm{p}<0.001)$, supervision $(\mathrm{b}=1.11 ; 95 \% \mathrm{CI}=0.27$ to $1.95 ; \mathrm{p}=0.009)$, and strong motivation $(\mathrm{b}=1.65 ; 95 \% \mathrm{CI}=0.76$ to $2.53 ; \mathrm{p}<0.001)$. It was directly and negatively affected by high work burden $(b=-1.05 ; 95 \% \mathrm{CI}=-1.92$ to $-0.18 ; \mathrm{p}=0.018)$. Midwife work performance was indirectly affected by training and incentive.

Conclusion: Work performance of midwives is directly and positively affected by good knowledge, tenure $\geq 13$ years, supervision, and strong motivation. It is directly and negatively affected by high work burden $(b=-1.05 ; 95 \% \mathrm{CI}=-1.92$ to $-0.18 ; \mathrm{p}=0.018)$. Midwife work performance is indirectly affected by training and incentive
\end{abstract}

Keywords: midwife, work performance, motivation, work burden, path analysis

\section{Correspondence:}

Latifah Nur Rahmadani. Masters Program in Public Health, Universitas Sebelas Maret. Jl. Ir. Sutami 36A, Surakarta 57126, Central Java. Email: latifahnr8@gmail.com. Mobile: 085250118907 